\title{
SOCIAL COHESION IN THE REPUBLIC OF MOLDOVA: REALITIES AND PERSPECTIVES
}

\author{
Victor MOCANU ${ }^{1}$, PhD, Associate Professor, \\ Institute of Legal, Political and Sociological Research, Republic of Moldova \\ Ludmila MALCOCI ${ }^{2}$, PhD, , Habilitate, Professor, \\ Institute of Legal, Political and Sociological Research, Republic of Moldova \\ Angela MOCANU ${ }^{3}$, PhD, Associate Professor, \\ Institute of Legal, Political and Sociological Research, Republic of Moldova
}

DOI: https://doi.org/10.36004/nier.es.2021.1-09

JEL Classification: A13, A14, C31, H80, I3, I31

UDC::316.7(478)

\section{ABSTRACT}

Strengthening social cohesion is one of the main directions of the Moldova 2030 strategy. At the same time, the Association Agreement between the Republic of Moldova and the EU stipulates social inclusion, poverty reduction, social cohesion, sustainable development and improving the quality of life as social policy priorities. This article analyzes the theoretical approaches of the concept of social cohesion and presents the results of sociological research on social cohesion in the Republic of Moldova conducted in 2020. The sample includes 1202 respondents and is representative by place of residence (urban / rural), sex, age, level of education. The qualitative study included interviews with 90 experts, representatives of local public authorities, NGOs and the private sector and 3 focus groups. The research was carried out within the project "Training and strengthening social cohesion in the Republic of Moldova in the context of rapprochement with the European Union". As key aspects of social cohesion were analyzed: self-identification of the degree of belonging of Moldovan citizens to the Republic of Moldova, perceptions of solidarity with other citizens, social trust, participation and inclusion of citizens in political, social and economic processes. The research results showed that the level of cohesion and social solidarity in the Republic of Moldova is quite low. The COVID-19 pandemic has deepened social distancing, uncertainty about the future, poverty and the marginalization of certain groups of the population and has further contributed to lowering the level of social cohesion.

Key words: social cohesion, social inclusion, social trust, solidarity.

Consolidarea coeziunii sociale este una dintre direcțiile principale ale strategiei Moldova 2030. În același timp, acordul de Asociere dintre Republica Moldova și UE stipulează incluziunea socială, reducerea sărăciei,coeziunea socială, dezvoltarea durabilă și îmbunătățirea calității vieții drept priorități ale politicilor sociale. Acest articol analizează abordările teoretice ale conceptului de coeziune socială și prezintă rezultatele cercetărilor sociologice privind coeziunea socială în Republica Moldova realizate în anul 2020. Eșantionul include 1202 de respondenți și este reprezentativ în funcție de locul de reședință (urban / rural), sex, vârstă, nivel de educație. Studiul calitativ a cuprins interviuri cu 90 de experți, reprezentanți ai autorităților publice locale, ONGurilor și sectorului privat și 3 focus grupuri. Cercetările au fost realizate în cadrul proiectului „Formarea și consolidarea coeziunii sociale în Republica Moldova în contextul apropierii cu Uniunea Europeană". Ca aspecte cheie ale coeziunii sociale au fost analizate: autoidentificarea gradului de apartenență a cetătenilor moldoveni cu statul Republica Moldova, percepțiile privind solidaritatea față de ceilalți cetățeni, încrederea socială, participarea și incluziunea cetățenilor în procesele politice, sociale și economice din țară. Rezultatele cercetării au arătat că nivelul de coeziune și solidaritate socială în Republica Moldova este destul de redus. Pandemia COVID-19 a aprofundat distanțarea socială, neîncredere în ziua de mâine, sărăcia și marginalizarea anumitor grupuri de populație și a contribuit și mai mult la scăderea nivelului de coeziune socială.

Cuvinte-cheie: coeziune socială, incluziune socială, încredere socială, solidaritate.

\footnotetext{
${ }^{1}$ ID ORCID 0000-0001-8769-6730 $\$ e-mail atitudinemd@gmail.com

${ }^{2}$ ID ORCID 0000-0002-7249-595 e-mail Imalcoci@keystonehumanservices.org

${ }^{3}$ ID ORCID 0000-0002-9996-7478 e-mail aiasinsky@gmail.com
} 
Укрепление социальной сплоченности является одним из основных направлений стратегии «Молдова 2030». В то же время Соглашение об ассоциации между Республикой Молдова и ЕС предусматривает повышение социальной интеграции, сокращение бедности, укрепление социальной сплоченности, устойчивое развитие и повышение качества жизни как основные приоритеты социальной политики. В статье анализируются теоретические подходы в определении концепции социальной сплоченности и представлены результаты социологических исследований социальной сплоченности в Республике Молдова, проведенных в 2020 году. Выборка включает 1202 респондента и репрезентативна в зависимости от места жительства (город / село), пола, возраста и уровня образования респондентов. Качественное исследование включало интервью с 90 экспертами, представителями местных органов власти, НПО и частного сектора, а также с 3 фокус-группами. Исследования проводились в рамках проекта «Формирование и укрепление социальной сплоченности в Республике Молдова в контексте сближения с Европейским Союзом». В качестве ключевых аспектов социальной сплоченности были проанализированы: самоопределение степени принадлежности молдавских граждан к государству Республика Молдова, восприятие солидарности с другими гражданами, социальное доверие, участие и включенность в политические, социальные и экономические процессы. Результаты исследования показали, что уровень сплоченности и социальной солидарности в Республике Молдова довольно низкий. Пандемия COVID-19 усилила социальное дистанцирование, неуверенность в завтрашнем дне, бедность и маргинализацию определенных групп населения, а также способствовала снижению уровня социальной сплоченности.

Ключевые слова: социальная сплоченность, социальная интеграция, социальное доверие, солидарность.

\section{INTRODUCTION}

In 2000, Social cohesion became one of the priorities set by the European Commission in terms of social policy at European Union level. Strengthening social cohesion is one of the main directions of the Moldova 2030 strategy. The Association Agreement between the Republic of Moldova and the EU also stipulates social inclusion, poverty reduction, social cohesion, sustainable development and improving the quality of life as priorities of social policy.

In this article we aim to study social cohesion in the Republic of Moldova from the perspective of self-assessing the degree of Moldovan citizens' belonging to the Republic of Moldova, perceptions of solidarity with other citizens, social trust, participation and inclusion of citizens in the country's political, social and economic processes.

\section{THEORETICAL APPROACHES REGARDING THE SOCIAL COHESION CONCEPT}

Literature does not present a single and well-defined notion of social cohesion, which is interpreted according to the discipline of study. In the Dictionary of Sociology, the notion of cohesion is defined from a social perspective, denotes the characteristics of this phenomenon and highlights the positive and negative sides of the phenomenon from the perspectives of the individual and the group The development of the social cohesion concept was based on sociological and psychological research with reference to the dynamics of social groups. We mention the research of crowd psychology by Gustav le Bon (1896), which determines the influence of the crowd on the behavior of the individual; the studies of Emil Durkheim (1897) on the phenomenon of suicide, according to which it is concluded that the suicide rate in various communities depends on their degree of solidarity; the experimental research of Iacob Moreno (1934) on the dynamics of the development of relationships in groups and their influence on the behavior of individuals; Leon Festinger's studies that led to the formalization of the theory of group cohesion, according to which cohesion is a key phenomenon of the continuity of membership, the cement that unites the members of a group and maintains the relations between them. Considerable contribution to the development of the notion of social cohesion has also been made by research on social networks (Jenson et al., 1998).

In her work on mapping social cohesion, Jane Jenson defines social cohesion as a continuous process of developing a human community with shared values, shared challenges and equal opportunities, which is based on trust, hope and reciprocity. At the same time, the researcher identifies five basic dimensions for measuring social cohesion, namely: belonging/isolation, 
inclusion/exclusion, participation/non-involvement (Dimeglio et al., 2012).

These dimensions allow the measurement of the phenomenon of social cohesion from several perspectives on a scale from total rejection to total inclusion. Thus, for example, group membership can be measured from total isolation to total inclusion of respondents at the level of groups, communities, society. In the case of inclusion/exclusion, we can measure the phenomenon from total social exclusion to inclusion in certain areas or even the inclusion of social groups at the community and society level.

Paul Bernardt develops Jenson's approach. He proposes measuring social cohesion from two perspectives: social spheres (economic, political, social, cultural) and social relations (at the level of attitudes and behaviors). Bernardt proposes 6 dimensions for measuring social cohesion: insertion/exclusion, legitimation/non-legitimation, recognition/rejection, equality/inequality, participation/passivity, affiliation/isolation.

Bernardt considers social cohesion as a quasi-concept, a hybrid mental construction developed by political games, which is based on the analysis of data in certain contexts. This construction is natural to remain indefinite in order to be adapted to the needs of political action (Dimeglio et al., 2012). Thus, the multidimensional analysis of social cohesion based on socio-psychological approaches at the level of social spheres and at the level of attitudes and behaviors is introduced. At the same time, a new aspect is introduced for the research of equality/inequality, ensuring comprehensive measurement.

Andy Green and Jan Germen Janmaat analyze social cohesion from the perspective of social institutions, attitudes and behaviors. Thus, they mention that social cohesion includes certain societal characteristics related to attitudes and behaviors as well as certain social institutions and mechanisms. With reference to social institutions and mechanisms, they include the following: risk-sharing and social protection mechanisms (state based on social welfare); redistribution mechanisms (such as taxes) to ensure equal and fair opportunities; and conflict resolution mechanisms (Green and Janmaat, 2011). Thus, social cohesion is defined more from the perspective of common values and ensuring social solidarity based on equity, equality, tolerance and behavior in accordance with the law. Social cohesion is analyzed more from the perspective of respecting living together in order to ensure people's rights and maintain society in a sustainable way.

O'Conner defines social cohesion from the perspective of values, differences, associations and networks, adding the category of infrastructure here. He considers that social cohesion covers three categories of issues: values, identity, culture that define a certain community; differences and divisions: inequalities and inequities, cultural diversity, geographical divisions; associations and networks, infrastructure (Noll, 2009).

According to Chan and others, social cohesion is a state that refers to the interactions between members of society vertically and horizontally. These interactions are based on attitudes and norms that include trust, a sense of belonging and a willingness to participate and help, as well as their behavioral manifestations. They propose a definition based more on the need to operationalize the phenomenon and consider that members of a community show cohesion if three conditions are met cumulatively:

1. they trust, help and cooperate with other members of the community;

2. they share a common identity or a sense of belonging to the community;

3. the subjective feelings made explicit in (1) and (2) are objectively manifested in their behavior (Chan et al., 2006).

In the context of measuring stability and reconciliation in countries with stagnant conflict, the SCORE index (www.scoreforpeace.org) is used, which measures two preconditions for peace and society: social cohesion between groups and reconciliation. According to him, social cohesion is measured on the basis of three indicators: 1) trust in institutions, 2) human security and 3) satisfaction with life. Reconciliation is measured on the basis of indicators: negative stereotypes, anxiety within the group, social distance, social dangers, active discrimination and positive feelings.

Measuring social cohesion in pandemic situations requires new dimensions and indicators that should be researched. Of particular interest in this context are studies of social cohesion in exceptional situations caused by natural or social calamities, which show that people show a greater degree of cooperation when they are in survival situations (Calo-Blanco et al., 2017) and that social cohesion contributes to reducing the perception of risk and fear, while trust in social support increases the degree of involvement in problem solving (Babcicky and Seebauer, 2020). 
In the Republic of Moldova, the phenomenon of social cohesion has been researched from several perspectives. In one of the first works (Negură et al., f.a.), the methodological framework for assessing social exclusion in Moldova was developed and it was concluded that there is an intrinsic link between social exclusion and social cohesion, in a cohesive society, the level of exclusion social being lower and vice versa. The research is based on the definition of social cohesion proposed by the Council of Europe according to which it means the capacity of society to ensure the well-being of all its members by minimizing economic, social, political disparities and avoiding the marginalization of people. Social cohesion would therefore require the ability of all to participate in economic life, benefiting from opportunities for development and social welfare. The analysis of social cohesion from the quality of life perspective identified five vulnerable groups in the Republic of Moldova: people with disabilities, children and families with many children, people with low incomes, youth, elderly and families of migrant workers.

Researchers Negură P., Mocanu V., Potoroacă M. analyze social cohesion from the perspective of social quality theory. Social cohesion is presented as an expression of the nature of social relations based on belonging, solidarity, trust, shared values and norms. The research results demonstrate the low degree of trust of the population in institutions and peers. Although the spirit of self-help exists in Moldovan society, social solidarity is also appreciated by respondents at a low level. At the same time, the sense of belonging of the respondents to their country and culture is quite high (Negură et al., f.a.).

\section{MAIN COMPONENTS OF SOCIAL COHESION}

Social cohesion is a multifaceted phenomenon that depends on certain social contexts and is very difficult to measure with the same categorical apparatus. Most research on social cohesion, in particular that carried out by the OECD, the Council of Europe and the European Commission, uses the following as its basic dimensions: social welfare, social capital and social mobility.

Social welfare is analyzed as a complex phenomenon, in a comprehensive logical framework, which is based on three aspects: material living conditions, quality of life and sustainability, or conditions that must be respected to preserve social welfare for other generations. Social welfare is analyzed both at the objective (concrete level of material living conditions) and subjective level, or at the level of perceptions, feelings, such as the degree of well-being satisfaction or the degree of security/insecurity. In the case of material conditions, researchers usually analyze the following dimensions: 1) income and consumption, 2) work and wages, 3) housing. Quality of life includes the following indicators: 1) health, 2) work and rest, 3) education and skills, 4) civic engagement and governance, 5) social connections, 6) personal security, 7) subjective well-being. Health is very important in terms of value, but it is also an important factor and a condition for employment. Equally, employment is important from the perspective of personal selfaffirmation and family well-being. Social connections are important for personal security and for the social valorization of individuals. An environment where people feel personally secure is very important for a beautiful and safe life. So practically all these dimensions together are important for ensuring social wellbeing and a high quality of life.

Measuring social welfare in OECD countries has highlighted certain trends in social cohesion, as follows. Income inequality continues to be very high in some countries, with high incomes mostly concentrated in the upper strata. There are many health disparities in social groups with different income levels, due in large part to different lifestyles. Women have a longer average life expectancy than men, but they report a lower level of health and a higher level of disability. The distribution of family obligations continues to be gender inequitable, so men work more hours at work and women work more hours at home without being paid. The elderly, the poor and the low-educated have far fewer social support networks than other population groups. People living in big cities and men are more likely to be victims of crime than other population groups. Poor, well-educated people and young people are less involved in politics than other population groups. These differences are also very big depending on the country's level of development. Thus inequality is higher in underdeveloped countries compared to other countries. The level of development of countries should be considered when measuring social cohesion (OECD, 2011).

Social capital is the second aspect considered important by researchers for measuring social cohesion. In the literature there are two approaches in measuring social capital: 1) from the perspective of the frequency of relationships and the possibility of obtaining social capital (information, ideas, support) from other individuals and other groups and 2) from the perspective of nature and fence 
involvement in various civil society networks and organizations. The World Bank measures social capital through 6 dimensions: 1) Groups and networks (involves the degree of belonging to different groups and networks, including civil society parties and organizations, and the degree of offering/receiving information, ideas, support); 2) Trust and solidarity (trust in institutions, neighbors and foreigners); 3) collective action and cooperation (if it happens in the community and how the members of the community cooperate in solving common community problems). This dimension also includes perceptions of collective action. In turn, the OECD has identified several perspectives from which social capital can be measured: 1) personal relationships (network structure and associated behaviors to maintain relationships), 2) support from social networks (emotional, financial, material, intellectual resources to who have access to network members), 3) civic involvement (activities and networks through which people contribute to community life, 4) trust and cooperative norms (trust, social norms and shared values). Social mobility is the third dimension most frequently involved in measuring social cohesion. From the OECD perspective, social mobility is perceived as intergenerational mobility between parents and children or grandchildren and as intra-generational mobility during the life of individuals. Intergenerational mobility analyzes the status of the individual from the perspective of income, occupation, health, education comparative with his parents. Intra-generational mobility analyzes how incomes and occupational status of individuals have changed over a lifetime. So mobility shows how the quality of life, occupational status, education, health, etc. have changed during the life of individuals and compared to their parents. High social mobility means that regardless of status, everyone has opportunities and chances to progress in their career or life (OECD, 2018).

\section{RESEARCH METHODOLOGY}

The results of the quantitative and qualitative sociological investigations carried out within the "Formation and consolidation of social cohesion in the Republic of Moldova in the context of the approach to the European Union" project in 2020 were used as empirical material.

The applied research tools were: the analysis of statistical data presented by the NBS, sociological survey administered by face-to-face and online interviews on a sample of 1202 people. The general population research sample consisted of 1202 randomly selected people. The sample is representative depending on the environment of residence, sex, age, level of education. Thus, depending on the environment of residence, $59 \%$ of people from rural areas and $41 \%$ from people from urban areas were surveyed. Depending on gender, $52 \%$ women and $48 \%$ men were surveyed. Depending on age, the respondents are divided as follows: ages 18-24 - 13\%, ages 25-29 - 14\%, ages 30-39 - $20 \%$, ages 40-49 $24 \%$, ages 50-64 - 18\%, ages 65+-11\%. Depending on the studies, respondents may be distributed as follows: primary/secondary education - 17\%, secondary/high school - 24\%, professional technical/vocational studies - 34\%, higher/postgraduate - 30\%.

The qualitative research included the interview with 90 experts, representatives of local public authorities, NGOs and the private sector and was conducted between May 8-26, 2020, while the quantitative one between July 18 and August 23, 2020

Prior to conducting basic field research, social cohesion research indicators were piloted into three focus groups to see to what extent they fit the situation in Moldova and to identify possible new indicators specific to the social context in our country. Thus, a total of 31 people participated in focus groups. In these focus groups we focused in particular on the following aspects: social solidarity, manifestation of cohesion at community level, belonging to social groups, inclusion and participation, trust in institutions and individuals.

\section{MAIN RESULTS}

Solidarity and social cohesion. Most focus group participants understand the notion of solidarity as follows: be united, help each other, be equal, listen to each other. Although most of them understand the importance of solidarity and social cohesion, about $2 / 3$ of the participants mentioned that in their locality the degree of solidarity and social cohesion is quite low. Each in his own nest, his own yard. We're not very friendly like that - woman, age 50, rural. 
Most often people help each other only if they are related. Most people lack initiative. If it is necessary to solve a community problem, for example to clean a well, people only organize if the initiative comes from the mayor or local councilmen. In the conditions when someone would need help, then he would address first of all the relatives, then he would address the mayor's office.

Focus group participants also agreed that the richer people are, the less supportive and needy they are. If they needed help, they would address poorer people, since they are more open. - Less wealthy people are kinder. They have the same hardships and understand more easily. The rich live in another world and don't understand each other - woman, 30.

When asked to what extent they would help strangers, the vast majority mentioned that they would rather be vigilant and that they would rather get to know the person than let them into the house or help them. Some mentioned that they had cases when they received strangers in the yard, served them with food and wine, but preferred that they not enter their house. - I can give you an example. A year or two ago, a stranger came on a motorcycle and came into my yard. I see he speaks German. He points at my house ... I say no, I won't let him in... Yes, I received him, gave him, I gave him a bottle of wine. He explained to me that he wanted to pitch his tent. Yes I will help you. But I won't let you in the house. I apologize, but... I mean, I was scared. It depends on the help needed. Otherwise, if something happened to him, I think I would help him, even if he's a foreigner - Man, 45, rural.

Many people mentioned that the degree of solidarity and cohesion is low in their communities because people are divided, most often, by political interest. Namely, politicians, from the focus group participants' perspective, made the local populations argue, hate each other. Society is dispersed by parties, by interests ... in our community, and throughout the republic. It was the goal of politicians to disperse them. Once the party is gone, the main expert changes, no matter how good he is. It doesn't matter. Another one comes, even if he is much weaker, more uneducated than the other one. This, unfortunately, is the truth, Man, age 40, urban.

Others mentioned that people are more divided on ethnic grounds and that until the citizens of this country, regardless of whether they are Moldovans, Romanians, Russians, etc., understand that they must respect the country's people, its history and language we cannot hope for cohesion and solidarity. For some of the participants, the union with Romania would be a solution. - Moldovan society is divided only because of our rulers who, for some reason, lean out towards the Russians who pay them 800 thousand Euros per month to maintain their parties, and of course they will try as much as possible to destroy this country and turn it into a bridgehead for the Russians. So we should unite, take them down, form a provisional government that would negotiate for the union with Romania. I think this would be the only way out of the swamp we are in. - Man, 55, rural.

Belonging to social groups. The vast majority of participants in focus groups mentioned that they are proud of their locality, even if the infrastructure is not very developed, they have many good people, the land is very fertile and they have a lot of greenery around.

If they go abroad, they are proud to be from the Republic of Moldova. There is one thing that they regret, namely that although the country is beautiful, the leaders at the helm of the country do not know how to lead and do not think about the country and the people who live here, but more about their own good. No matter how good it would be elsewhere, it's not good here. Our country is always different. We simply do not have a leadership, which should lead us properly. If we were to have good leadership, we would be supportive. I stayed in Canada for a month this summer and saw very beautiful things, but I still missed this place - Woman, aged 60, urban.

Some mentioned that they have children abroad and they also say that they are from the Republic of Moldova because Moldovans are much more appreciated than other peoples in other countries for their kindness and diligence. - Let's put it this way, I have children who went abroad, for them it is more proud to say thatyou are from the Republic of Moldova, than from Romania. Because they don't really love Romanians, they don't like them abroad, they consider them thieves. - Man, 60, rural - I was in Germany for a while and saw a similar situation. The attitude towards Moldovans is more positive than towards other nationalities. Man, age 45, rural.

When asked about what qualities must a good citizen of the Republic of Moldova possess, the participants in the focus groups mentioned the following: cult, smart, honest, not to be a thief, not to be corrupt, to love their country and not to criticize it, to love the people and to care for the people, to have moral values, to be altruistic, to actively participate in community activities, to be people with verticality. 
Trust in people and institutions. When asked if they generally trust people, the absolute majority mentioned that they would rather not trust them, because people are different and they change very easily depending on the circumstances. Now people are two-faced. Even if we take the elections ... people go after everyone, they are unpredictable. Man can do anything, what he does not expect he can do. They go with the flow, they agree with everyone. Man is not specific. For example, he has an option, he doesn't have his option, anyone can fool him. A good part is like that. Woman, 45, rural.

Respondents show the greatest confidence in their family members, colleagues and neighbors. With reference to social institutions, the participants in the focus groups mentioned that they have more trust in the church and the mayor's office, and less trust in the Government, Parliament, Police, trade unions. - Church is the place where persons alleviate their needs, problems, which they have with society, with family. Not trusting today's politics, they find comfort there. Second, where do people go to share their trouble? Local council. His hen got stolen, he goes to the local council, he was insulted, has no wood, he goes to the local council. Not trusting others, people limit themselves to family, church, local council hall - that's my opinion. Man, 60, rural.

Thus, with reference to the church and its role in the community, respondents mentioned that it has an educational role, of consolidating the society, and the priest must be a model of behavior for the village. Although they trust the church, some participants in focus groups mentioned that in some localities the church has become involved in politics, which is not a good thing at all. - The church became politically involved; this is the worst thing that may happen in a state. The church must have its place. It belongs to the spiritual, not the material. Man, 60, urban.

Other respondents mentioned that the behaviors of priests often leave much to be desired: they do business at church instead of helping poor people, they are not interested in the problems of the parishioners. It is for these reasons that some people have lost faith in the church today. - I want to tell you that a priest should know more about the villagers. My mother is 89 and she goes to church every Sunday, if she doesn't go there for two or three Sundays, if I were a priest, I would come and ask her why did she not come for two or three days? Maybe you're sick, maybe you need something ... Woman, 50, rural -These fees, these candles. Well, if I went to church with a candle from home, he doesn't have the right to force me to buy a candle from church, that's not a place of business. You don't go there to do business; you go there to pray. Man, 50, urban

When asked if they trust the army, some respondents gave a positive answer, because the army has an educational purpose, while others said that in general Moldova should not have an army, because it is a small country that tries to assure everyone that it is neutral. In addition, many young people avoid the army - they rather go to colleges, universities, or even work abroad to escape the army. Youth from vulnerable families, who have nowhere to go, usually enlist in the army.

With reference to the police, most mentioned that they do not trust because the police do not do their job, often do not register applications, it is very difficult in rural areas to find a police officer when you need one. Before, the police did their job. When there was a district policeman in every local council. Now we don't have a local policeman. Folks come once a month to write a complaint, they don't discuss, they take the requests and hide them, not all of them are registered. Man, 60, rural.

The unions, in the vision of the participants in the focus groups, lost their responsibilities, they are more involved at indication of government officials, or in the best case in the organization of some festive events. For these reasons, the vast majority of people do not trust this institution and would never turn to trade unions for solutions. What does an agricultural union do? It unites farmers, defends rights, goes to the ministry of agriculture, goes to the marketplaces, raises the masses... In our unions there are a bunch of people throwing some rubles back for a tea, a celebration. Before, no employee could be fired until the union agreed. Regardless, the president of the country may say anything ... the union is a neutral body, they meet, they put things on the table after the elections, not their personal interests... this is how this was seen. They give notice. And even when bosses exceed their duties, for which they also find a suitable article, he goes to court and get defense. That is the mission of a union. They go to court and get defense... we thought the leader had exceeded his duties. Man, 56, rural

Focus groups participants mentioned they have the least trust in Parliament and Government. These structures do not fulfill their mission, they do not take care of the country and the people. People have chronic distrust in leadership. Many of those in charge were taught by our teachers. They're from our 
country. The education process begins in the family; it begins in school. When they gather, they discuss less about the interest of the state with personal, group interests predominating. It means we won't get over this handicap soon. We did not have political traditions, political parties in the true sense of the word, for the political elite to be chiseled. - Man, 57, urban.

With reference to trust in parties, focus group participants mentioned that they do not trust a party either, because they do not have political values and goals, party members frequently change from one party to another for money. People also mentioned that a new political class is needed to make changes at the societal level.

Diversity and tolerance. People in communities have a rather low spirit of tolerance, especially towards Muslims and refugees from other countries. They consider that the Republic of Moldova still invests too much in refugees. Many of them mentioned that although they know that in other countries refugees are helped by the population, they personally are not sure they would help refugees. - Especially when a man of another faith comes to our society, he first of all cannot integrate. No one will tolerate him imposing his rules of the game. I don't think our Moldovans will give in and let him do his will. That is my opinion. -Man, 47, rural - We still have enough refugees, and they are paid and have pardons in all respects. The native population does not have such privileges. I know the place where refugees live in Moldova, and they have so many conditions there that an ordinary man who works every day does not have and neither does he have the rights that refugees have. Man, 56, urban.

Perspectives for the future. When asked about the prospects of their community, most respondents were very pessimistic, noting that they have the example of other localities, where people migrate en-masse and that if the situation in the country remains the same, all villages, including theirs, will become deserted. Some mentioned that they still hope for more educated Moldovans to return from abroad and develop the country's economy and localities, as the Italians, or other peoples, once did. - The Moldovans will return in any case. Like with Italy, for example, in 1959 they went to America, came back with capital, opened hotels, and things went pretty well. - Man, 47, rural.

Research on social cohesion in social welfare, social capital and social mobility dimensions showed that the level of cohesion and social solidarity in Moldova is quite low. The COVID-19 pandemic deepened social distancing, fears, poverty and marginalization of certain population groups and further contributed to lowering the level of social cohesion.

\section{SOCIAL COHESION FROM THE SOCIAL WELFARE STANDPOINT}

The socio-economic security of Moldova's population is quite low. Extreme and absolute poverty levels, although in slight decline in recent years, remain quite high. The impoverishment of the population is fueled by limited jobs, a high consumer price index and high rate of inflation. Poverty continues to affect the rural population the most, large families and many children, children and the elderly. Although the average monthly income of the population continued to increase, in the context of rising consumer prices and inflation, they continue to be insufficient to ensure a decent living of more than $2 / 3$ of the country's population. Access to various quality community services (water, sewerage, district heating, etc.) is low, especially in rural areas, low-income families, families with many children and elderly families. In the context of the pandemic, the socio-economic situation of marginalized families has worsened further, due to the loss of jobs and the emergence of new expenses - protective materials against COVID or even medicine in cases of illness; the need to provide children with computers or internet to learn online; increased housing maintenance costs due to the transfer of the workplace to the home, etc. At the same time the very low involvement of the authorities in supporting these families is worth mentioning. In the context of the above, more than half of the country's population is not satisfied with their lives in general. The share of dissatisfied people is higher in rural areas, in age groups 50+, in the environment of people with low education, those not employed, people with low incomes.

\section{SOCIAL COHESION AND SOCIAL CAPITAL}

The analysis of the respondents' degree of participation in politics and community life shows that the vast majority of the population is practically not involved in the community political or social life. Election participation is the only political and civic activity involving over $2 / 3$ of the population. The share of more active people in political and social life is higher among those who work in the public sector, are 
party or NGO members. The fiscal morale of the population is rather at the level of attitudes and beliefs regarding payment of salary taxes, and less in relation to informal payments, about $1 / 3$ of those surveyed having offered informal payments in the last 12 months.

In general, the population has a high level of trust only in family members, friends, co-workers and neighbors; the level of trust in institutions remains quite low. Compared to different institutions, the population has more trust in the Church, the media, the mayor's office and the Presidency and less trust in Justice, the Prosecutor's Office, political parties, Parliament and Government. The level of trust in most people, as well as in strangers is very low, people considering that they have to be very vigilant with them. Regarding media, respondents have more trust in the media in the EU and Romania and less trust in the media of Moldova and Russia. The frequency of media consumption is quite high among the population, the most important source of information being considered television, and the most credible the Internet.

The analysis of the identity and group membership of the population shows that most respondents are proud of being citizens of Moldova, although many of them do not associate this feeling with the greater possibility of assertion, a perfect place for raising children, or for living and working and about $60 \%$ are oriented to leave the country in the near future. This feeling of pride is rather explained by the unconditional love for the place where they were born, raised and educated and of belonging to the nation. Most respondents continue to identify themselves as residents of their city/village and a citizen of Moldova, and less so as a citizen of Europe or a citizen of the planet. At the same time, a large part of the population identifies itself with the ethnic group to which it belongs and only $16 \%$ consider themselves simply citizens of Moldova.

The analysis of the social distance between respondents and different marginalized groups of population or ethnic groups highlighted the fact that the smallest social distance is between respondents and Moldovans, Romanians, Russians, who are perceived as close social groups, who may be part of family members, colleagues, neighbors. The social distance index is moderate and shows tolerance towards the following groups: Jews, people with physical and mental disabilities, Roma, immigrants, HIV + persons, persons of color, former detainees, Muslims, homeless persons. Respondents acknowledge that these groups may live in their community, or even in the country, but also want them less as family members, neighbors, colleagues, friends. The index of social distance between respondents and drug users and homosexuals denotes isolation; thus, the respondents would like these groups to leave the country.

\section{SOCIAL COHESION FROM THE SOCIAL MOBILITY PERSPECTIVE}

Social groups with high social status are in all cases characterized by the following: high level of education, high share of urban population, high occupational status, and vice versa - groups with low social status include people with low education, from rural areas, with low occupational status.

Education is one of the basic factors leading to intra-generational social mobility. The higher the level of education, the more likely the possibility to advance on the social scale. And vice-versa, a low level of education decreases opportunities to increase social status.

In the case of extreme groups (with the highest and lowest status) inter-generational occupational mobility is the highest: with a descending or ascending specific. In the case of groups of highly and medium qualified specialists, the share of those who maintained the occupational status of their fathers was $56 \%$ and $67 \%$.

With regard to the standard of living of the respondents compared to that of the parents, in the groups with higher social status the share of respondents who mentioned that they have a better/much better life compared to their parents gradually increases and respectively the share of those who consider that they have a worse/much worse life than their parents. The same trend was observed in the perspective of children's living standards: in the groups with higher social status, the share of respondents who believe that their children will have a better life than them and vice-versa is higher.

\section{PRIORITY DIRECTIONS TO CONSOLIDATE SOCIAL COHESION}

Increasing the population's social well-being, and in particular disadvantaged groups (rural persons, persons with disabilities, youth, the elderly), through sustainable economic development, supporting small agricultural producers, creating fair employment opportunities, equitable distribution of income and the reduction of economic inequalities, the vocational guidance of youth in line with their 
interests and the needs of the labor market, increasing people's access to physical infrastructure, public utilities and living conditions.

Developing the sense of social responsibility of entrepreneurs to create inclusive work environments in line with the needs of employees. Develop incentives for employers, including taxation, to invest more in creating good working conditions, including those adapted to the needs of people with disabilities, and in developing human resources.

Ensuring equitable and free access to education services for all children, including disadvantaged groups - children with disabilities, from socio-economically vulnerable families, from rural areas, Roma, minor parents, providing the necessary support according to individual needs and ensuring a friendly, protective and inclusive school environment. Focusing the education system on person-centered education in order to develop such skills and competencies as critical and creative thinking, collaboration, flexibility, information technology, entrepreneurship, which will help them make decisions, solve problems and communicate effectively.

Ensuring the right of the population, especially marginalized groups, to quality social assistance and protection by strengthening capacity and developing innovative tools for data collection and benefit allocation, development of the network of care, rehabilitation, retraining and quality provision depending on needs.

Ensuring equitable access to quality health services, including for marginalized groups, by developing an efficient and flexible health insurance system, access to efficient, quality and affordable basic medicines and a high level of information to the public about their right to health; and medical services from which he may benefit, including on the basis of medical insurance.

Development and implementation of development policies at local and national level from the perspective of addressing human rights by making public decisions based on evidence of their impact on the population, especially marginalized groups, involvement of the population in decision making, ensuring a clear, efficient and inclusive implementation mechanism and monitoring decisions taken.

Ensuring safe, inclusive, non-discriminatory and equitable community and social environments for all population groups, including the marginalized, by integrating the principles of equality and nondiscrimination into all development policies and practices, involving marginalized groups in decisionmaking and monitoring policy implementation, implementation of communication campaigns focused on accepting differences and diversity and promoting a tolerant attitude.

Developing the spirit of cohesion and social solidarity at local and national level by stimulating and ensuring a governance in partnership with the citizens and assuming concrete responsibilities for community development. Developing effective partnerships between authorities and civil society for the social inclusion of vulnerable groups.

\section{REFERENCES}

1. Babcicky, P., \& Seebauer, S. (2020). Collective efficacy and natural hazards: Differing roles of social cohesion and task-specific efficacy in shaping risk and coping beliefs. Journal of Risk Research, 23(6), 695-712. https://doi.org/10.1080/13669877.2019.1628096

2. Calo-Blanco, A., Kováŕík, J., Mengel, F., \& Romero, J. G. (2017). Natural disasters and indicators of social cohesion. PLOS ONE, 12(6), e0176885. https://doi.org/10.1371/journal.pone.0176885

3. Chan, J., To, H.-P., \& Chan, E. (2006). Reconsidering Social Cohesion: Developing a Definition and Analytical Framework for Empirical Research. Social Indicators Research, 75(2), 273-302. https://doi.org/10.1007/s11205-005-2118-1

4. Dimeglio, I., Janmaat, J. G., \& Méhaut, P. (2012). Social Cohesion and the Labour Market: Societal Regimes of Civic Attitudes and Labour Market Regimes. Social Indicators Research, 111. https://doi.org/10.1007/s11205-012-0032-x

5. Green, A., \& Janmaat, J. G. (2011). Regimes of Social Cohesion. Palgrave Macmillan UK. https://doi.org/10.1057/9780230308633

6. Jenson, J., Réseaux canadiens de recherche en politiques publiques, Canada, \& Développement des ressources humaines Canada. (1998). Les contours de la cohésion sociale: L'état de la recherche au Canada. Réseaux canadiens de recherche en politiques publiques. 
7. Negură, P., Mocanu, V., \& Potoroacă, M. (f.a.). Coeziunea socială în Republica Moldova din perspectiva apartenenței, încrederii și solidarității sociale (2016-2018). 27.

8. Noll, H.-H. (2009, decembrie 4). Indicators for Social Cohesion in the European Union.

9. Organisation for Economic Cooperation and Development. (2011). How's Life?: Measuring Wellbeing. OECD. https://doi.org/10.1787/9789264121164-en

10. Organisation for Economic Cooperation and Development. (2018). A Broken Social Elevator? How to Promote Social Mobility. OECD. https://doi.org/10.1787/9789264301085en

\section{ARTICLE HISTORY}

Received 18 January 2021

Accepted 26 May 2021 